\title{
Temperature dependence studies on the electro-oxidation of aliphatic alcohols with modified platinum electrodes
}

\author{
PANADDA KATIKAWONG ${ }^{\mathrm{a}}$, TANAKORN RATANA ${ }^{\mathrm{b}}$ and WARET VEERASAI ${ }^{\mathrm{a}}$ \\ ${ }^{a}$ Department of Chemistry, Faculty of Science, Mahidol University, Bangkok 10400, Thailand \\ ${ }^{b}$ Department of Industrial Chemistry, Faculty of Applied Science, \\ King Mongkut's University of Technology North Bangkok, Bangkok 10800, Thailand \\ e-mail: pana_a@hotmail.com
}

MS received 13 June 2008; revised 18 February 2009

\begin{abstract}
Temperature dependence on the electro-oxidation of methanol, ethanol and 1-propanol in $0.5 \mathrm{M} \mathrm{H}_{2} \mathrm{SO}_{4}$ were investigated with $\mathrm{Pt}$ and $\mathrm{PtRu}$ electrodes. Tafel slope and apparent activation energy were evaluated from the cyclic voltammetric data in the low potential region $(0 \cdot 3-0 \cdot 5 \mathrm{~V}$ vs SHE). The $\mathrm{CV}$ results provided Tafel slopes for alcohols in the range of 200-400 $\mathrm{mV} \mathrm{dec}^{-1}$ which indicated a difference in the rate determining step. The decrease in Tafel slope was only observed in the case of methanol for the Ru-modified Pt electrode. This indicates that $\mathrm{Ru}$ improves the rate of determining step for methanol while hindering it for the other alcohols. The electrochemical impedance spectroscopy was also used to evaluate the electro-oxidation mechanism of alcohols on these electrodes. The simulated EIS results provided two important parameters: charge transfer resistance $\left(R_{c t}\right)$ and inductance $(L)$. The $R_{c t}^{-1}$ and $L^{-1}$ represent the rate of alcohol electro-oxidation and rate of desorption of intermediate species, respectively. These values increased with the increasing of temperature. The results from two techniques were well agreed that the electro-oxidation of methanol was improved by raising the temperature and ruthenium modification.
\end{abstract}

Keywords. Cyclic voltammetry; electrochemical impedance spectroscopy; activation energy; fuel cell; alcohol.

\section{Introduction}

The use of hydrogen carrier like alcohol as alternative fuels in the direct alcohol fuel cell (DAFC) appears that they are advantageous for two main reasons: (i) easy storage of liquid fuels and (ii) their high theoretical mass energy density, for example; 6.1 and $8.0 \mathrm{kWh} \mathrm{kg}^{-1}$ for methanol and ethanol, respectively. An emerging technology of DAFC uses liquid alcohols without an external fuel processing unit such as methanol, ethanol and propanol which made them more versatile in many portable products. ${ }^{1-5}$ DAFCs generate power through the direct oxidation of alcohol in conjunction with the reduction of oxygen (in air). The major challenges faced in DAFC are (i) methanol crossover which can only be overcome by developing new membranes; (ii) slow electrochemical kinetics at electrode/electrolyte interfaces which can only be overcome by develop-

*For correspondence ing new electrocatalysts for both anode and cathode. ${ }^{5-7}$ To date, Pt-based catalyst have been shown to improve the efficiency of DAFC in acidic electrolyte. ${ }^{5-9}$ Many metals such as $\mathrm{Ru}, \mathrm{Pd}, \mathrm{Sn}$ or $\mathrm{Rh}$ exhibit co-catalytic activity with $\mathrm{Pt}$ for the oxidation of alcohol via the bifunctional mechanism. ${ }^{5}$ The understanding of the relationship between the reaction pathway and their electrocatalytic activity at elevated temperature is necessary for developing the new catalyst in DAFC.

In this work, cyclic voltammetry (CV) was used to provide kinetic data while electrochemical impedance spectroscopy (EIS) was used to distinguish different elementary steps of the reaction process at desired bias potentials. The electro-oxidation of aliphatic alcohols including; methanol, ethanol, 1propanol on the well-defined Pt-based electrode were performed in the temperature range of 25 to $60^{\circ} \mathrm{C}$. Based on $\mathrm{CV}$ data, the kinetic parameters such as Tafel slope and apparent activation energy were evaluated. Through the analysis of EIS spectra, 

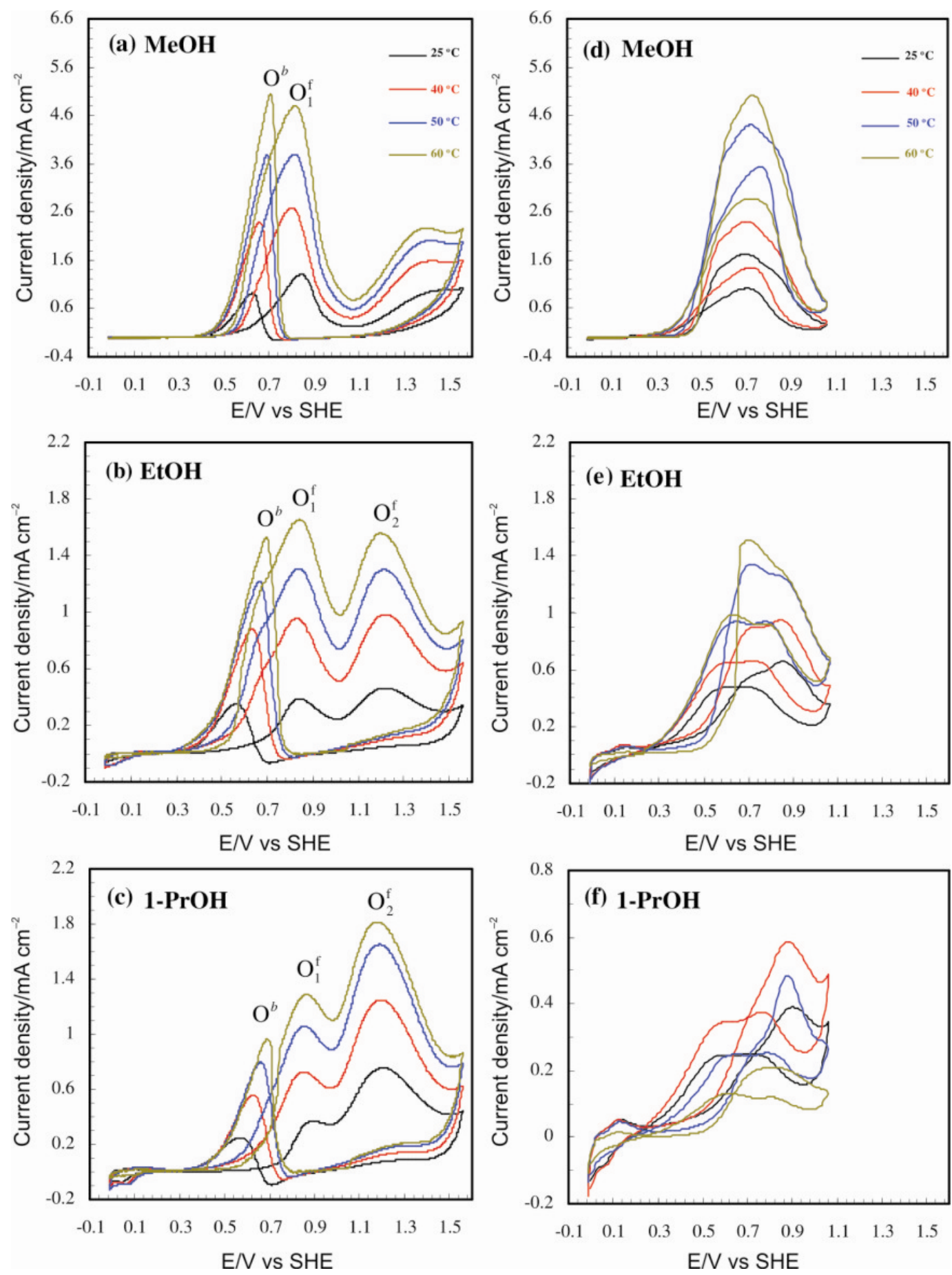

Figure 1. Cyclic voltammograms at different temperatures with $\mathrm{p}-\mathrm{Pt}$ electrode $(\mathrm{a}-\mathrm{c})$ and $\mathrm{p}$-PtRu electrode $(\mathrm{d}-\mathrm{f})$ in $0.25 \mathrm{M}$ methanol, $0.25 \mathrm{M}$ ethanol, and $0.25 \mathrm{M}$ 1-propanol. Scan rate $=0.05 \mathrm{~V} \mathrm{~s}^{-1}$.

we obtained the inverse charge transfer resistance and inverse inductance values which can be correlated with the rate of electro-oxidation of alcohols and the rate of desorption of intermediate species, respectively. Additionally, the reaction pathway of aliphatic alcohols $\left(\mathrm{C}_{1}-\mathrm{C}_{3}\right)$ is proposed and discussed in this study.

\section{Experimental}

\subsection{Chemicals}

All analytical grade chemicals were used in this work without further purification. The solution was prepared in deionized water $(18.2 \mathrm{M} \Omega \mathrm{cm}$, Milli-Q- 
system, Milford, Massachusetts, USA). The $0.25 \mathrm{M}$ methanol, ethanol and 1-propanol (Merck, Germany) were prepared in $0.5 \mathrm{M}$ of $\mathrm{H}_{2} \mathrm{SO}_{4}$ (Merck, Germany).

\subsection{Preparation of the modified electrodes}

The platinized platinum (p-Pt) electrode was prepared on a platinum wire (i.d. $=2.5 \mathrm{~mm}$ ). The electrode surface was electrochemically activated by cycling the potential between 0 and $1.15 \mathrm{~V}$ vs SHE at scan rate of $50 \mathrm{mV} \mathrm{s}^{-1}$ in $0.5 \mathrm{M} \mathrm{H}_{2} \mathrm{SO}_{4}$. Then, the $\mathrm{CV}$ was applied by cycling potential between $-0 \cdot 1$ and $-0.45 \mathrm{~V}$ vs SHE for 10 scans in $13 \mathrm{mM} \mathrm{H}_{2} \mathrm{PtCl}_{6}$ (Fluka, Switzerland). After platinizing step, the electrode was polarized at $-0.5 \mathrm{~V}$ vs SHE for $5 \mathrm{~min}$ in $0.5 \mathrm{M} \mathrm{H}_{2} \mathrm{SO}_{4}$ in order to eliminate chloride ions from the electrode surface.

The ruthenium modified $\mathrm{Pt}$ electrode ( $\mathrm{p}-\mathrm{PtRu}$ ) was prepared by electrodeposition technique. After the electrochemically activated step, the p-Pt electrode was immersed in $10 \mathrm{mM} \mathrm{RuCl}_{3}$ (Aldrich, USA) and fixed potential at $-0.07 \mathrm{~V}$ vs SHE for $100 \mathrm{~s}$.

\subsection{Electrochemical measurements}

The electrochemical measurements were investigated by cyclic voltammetry (CV) and electrochemical impedance spectroscopy (EIS) using a three electrode cell with temperature control unit. The working electrode was a $\mathrm{p}$-Pt or a p-PtRu electrode and the counter electrode was a $\mathrm{Pt}$ rod. The $\mathrm{Ag} / \mathrm{AgCl}$ electrode was used as reference electrode $(E=$ $0.206 \mathrm{~V}$ vs SHE) ${ }^{10}$ All potentials are given with respect to the standard hydrogen electrode (SHE). The electrochemical experiments were carried out under nitrogen atmosphere and measured with the AUTOLAB PGSTAT30 with FRA2 module (Eco Chemie B.V., The Netherlands), which was controlled by GPES and FRA software. The working electrode was activated by cycling potential between 0 and $1.15 \mathrm{~V}$ vs SHE at scan rate of $50 \mathrm{mV} \mathrm{s}^{-1}$ until the reproducible $\mathrm{CV}$ patterns were obtained. The cell temperature was controlled between 25 and $60^{\circ} \mathrm{C}$ within $\pm 0 \cdot 2^{\circ} \mathrm{C}$.

The electrochemical impedance spectra were recorded in the frequency range of $10 \mathrm{kHz}$ to $8 \mathrm{mHz}$. The amplitude of single sinusoidal modulation voltage was setting at $0.05 \mathrm{~V}$. All EIS spectra were recorded with bias potential of $0.4-1.0 \mathrm{~V}$ vs SHE.

\section{Results and discussion}

\subsection{Cyclic voltammetry (CV)}

Cyclic voltammograms of methanol, ethanol and 1propanol on a p-Pt electrode at different temperatures $\left(25,40,50\right.$ and $\left.60^{\circ} \mathrm{C}\right)$ are shown in figures lac. The oxidation peaks of the $\mathrm{CV}$ presented as $\mathrm{O}_{1}^{\mathrm{f}}$ and $\mathrm{O}_{2}^{\mathrm{f}}$ for the first and the second anodic peaks in the forward potential scan and $\mathrm{O}^{b}$ for the cathodic peak in the backward potential scan. At $25^{\circ} \mathrm{C}$, the first anodic peak $\left(\mathrm{O}_{1}^{\mathrm{f}}\right)$ appears around $0.84 \mathrm{~V}$ vs SHE with lower onset potential ( $E_{\text {onset }}=0.62 \mathrm{~V}$ vs SHE), which was well agreed with the beginning of the methanol electro-oxidation via adsorbed intermediates on $\mathrm{Pt} / \mathrm{C}$ electrode as reported by Lee et $a l .{ }^{11}$ The $\mathrm{O}^{b}$ peak appears around $0.69 \mathrm{~V}$ vs SHE which was attributed to the re-oxidation of the intermediate species. The effect of temperature in the range of 25 to $60^{\circ} \mathrm{C}$ showed the increasing in the anodic current density with increasing temperature. Moreover, a negative shift in the onset potential was also observed.

The electro-oxidation pathway of methanol consists of two processes necessary to complete the oxidation in different potential regions. First, hydrogen atom is discarded from the Pt surfaces at potential around $0.2 \mathrm{~V}$ and methanol can be adsorbed on the Pt surface as follows:

$$
\mathrm{Pt}-\mathrm{H}+\mathrm{CH}_{3} \mathrm{OH} \rightarrow \mathrm{Pt}-\mathrm{COH}+4 \mathrm{H}^{+}+4 \mathrm{e}^{-} \text {. }
$$

The second process requires the dissociation of water on vacancy of Pt sites which is the oxygen donor for the oxidation of the intermediate species to form $\mathrm{CO}_{2}$ at the potential above $0.45 \mathrm{~V} .^{12}$ The effect of increasing temperature may be explained from the increasing rate of both processes as follows:

$$
\begin{aligned}
& \mathrm{Pt}+\mathrm{H}_{2} \mathrm{O} \rightarrow \mathrm{Pt}-\mathrm{OH}+\mathrm{H}^{+}+\mathrm{e}^{-} \\
& \mathrm{Pt}-\mathrm{COH}+\mathrm{Pt}-\mathrm{OH} \rightarrow \mathrm{Pt}-\mathrm{CO}+\mathrm{H}_{2} \mathrm{O}+\mathrm{Pt} \\
& \mathrm{Pt}-\mathrm{CO}+\mathrm{Pt}-\mathrm{OH} \rightarrow \mathrm{Pt}-\mathrm{COOH}+\mathrm{H}^{+}+\mathrm{e}^{-} \\
& \mathrm{Pt}-\mathrm{COOH}+\mathrm{Pt}-\mathrm{OH} \rightarrow \mathrm{CO}_{2}+\mathrm{H}_{2} \mathrm{O}+2 \mathrm{Pt} .
\end{aligned}
$$

For the electro-oxidation of ethanol on p-Pt electrode at $25^{\circ} \mathrm{C}$ in figure $1 \mathrm{~b}$, the $\mathrm{O}_{1}^{\mathrm{f}}, \mathrm{O}_{2}^{\mathrm{f}}$ and $\mathrm{O}^{b}$ peaks were found at $0.83,1.23$ and $0.56 \mathrm{~V}$ vs SHE, respectively. The presence of $\mathrm{O}_{2}^{\mathrm{f}}$ peak was assigned as the oxidation of alcohol with $\mathrm{Pt}$ oxide surface. More negative potential value in $\mathrm{O}^{b}$ peak than the observed in re-oxidation peak of methanol were found. It was suggested that the intermediate species of ethanol 
Table 1. Electrochemical data at various temperatures of the three aliphatic alcohols oxidation on $\mathrm{p}-\mathrm{Pt}$ and $\mathrm{p}-\mathrm{PtRu}$ $\left(\theta_{\mathrm{Ru}}=0 \cdot 6\right)$ electrodes.

\begin{tabular}{|c|c|c|c|c|c|c|c|c|c|}
\hline \multirow{2}{*}{$\begin{array}{l}\text { Tempe- } \\
\text { rapture } \\
\left({ }^{\circ} \mathrm{C}\right)\end{array}$} & \multirow{2}{*}{$\begin{array}{c}\text { Onset } \\
\text { potential } \\
(\mathrm{V} \text { vs SHE) }\end{array}$} & \multicolumn{3}{|c|}{$\begin{array}{l}\text { Peak potential, } E_{\mathrm{p}} \\
\text { (V vs SHE) }\end{array}$} & \multicolumn{3}{|c|}{$\begin{array}{l}\text { Current density, } J \\
\qquad\left(\mathrm{~mA} \mathrm{~cm}^{-2}\right)\end{array}$} & \multirow{2}{*}{$\begin{array}{l}\text { Tafel slope } \\
\left.(\mathrm{mV} \mathrm{dec})^{-1}\right)\end{array}$} & \multirow{2}{*}{$\begin{array}{c}\text { Activation } \\
\text { energy } \\
\left(\mathrm{kJ} \mathrm{mol}^{-1}\right)\end{array}$} \\
\hline & & $\mathrm{O}_{1}^{\mathrm{f}}$ & $\mathrm{O}_{2}^{\mathrm{f}}$ & $\mathrm{O}^{b}$ & $\mathrm{O}_{1}^{\mathrm{f}}$ & $\mathrm{O}_{2}^{\mathrm{f}}$ & $\mathrm{O}^{b}$ & & \\
\hline 25 & $0 \cdot 62 / 0 \cdot 47$ & $0 \cdot 84 / 0 \cdot 69$ & - & $0.63 / 0.70$ & $1 \cdot 16 / 1 \cdot 58$ & - & $0 \cdot 99 / 0 \cdot 91$ & $178 / 74$ & $70 \cdot 4 / 54 \cdot 4$ \\
\hline 40 & $0.57 / 0 \cdot 46$ & $0 \cdot 80 / 0 \cdot 70$ & - & $0 \cdot 65 / 0.71$ & $2 \cdot 45 / 2 \cdot 21$ & - & $2 \cdot 42 / 1 \cdot 31$ & $118 / 65$ & \\
\hline 50 & $0 \cdot 56 / 0 \cdot 43$ & $0 \cdot 80 / 0 \cdot 70$ & - & $0.69 / 0.76$ & $3 \cdot 44 / 4 \cdot 03$ & - & $3 \cdot 85 / 3 \cdot 19$ & $97 / 54$ & \\
\hline 60 & $0 \cdot 55 / 0 \cdot 40$ & $0.81 / 0.71$ & - & $0 \cdot 70 / 0 \cdot 70$ & $4 \cdot 34 / 4 \cdot 63$ & - & $5 \cdot 15 / 2 \cdot 51$ & $83 / 71$ & \\
\hline 25 & $0 \cdot 60 / 0 \cdot 48$ & $0 \cdot 83 / 0 \cdot 71$ & $1 \cdot 23$ & $0 \cdot 56 / 0 \cdot 58$ & $0 \cdot 32 / 0 \cdot 31$ & $0 \cdot 28$ & $0 \cdot 41 / 0 \cdot 37$ & $211 / 165$ & $52 \cdot 2 / 22 \cdot 5$ \\
\hline 40 & $0 \cdot 54 / 0 \cdot 48$ & $0.82 / 0.71$ & $1 \cdot 21$ & $0.63 / 0.58$ & $0 \cdot 69 / 0 \cdot 6$ & 0.43 & $0.92 / 0.49$ & $277 / 157$ & \\
\hline 50 & $0.54 / 0.53$ & $0.82 / 0.71$ & $1 \cdot 21$ & $0 \cdot 66 / 0 \cdot 61$ & $0.91 / 1 \cdot 03$ & 0.53 & $1 \cdot 24 / 0 \cdot 67$ & $227 / 173$ & \\
\hline 60 & $0 \cdot 54 / 0 \cdot 51$ & $0.83 / 0.69$ & $1 \cdot 23$ & $0 \cdot 69 / 0 \cdot 61$ & $1 \cdot 21 / 1 \cdot 24$ & $0 \cdot 61$ & $1 \cdot 53 / 0 \cdot 72$ & $181 / 194$ & \\
\hline 25 & $0 \cdot 74 / 0 \cdot 49$ & $0 \cdot 86 / 0 \cdot 69$ & $1 \cdot 19$ & $0 \cdot 56 / 0 \cdot 55$ & $0 \cdot 14 / 0 \cdot 16$ & $0 \cdot 34$ & $0 \cdot 34 / 0 \cdot 16$ & $398 / 241$ & $32 \cdot 8 / 17 \cdot 1$ \\
\hline 40 & $0 \cdot 62 / 0 \cdot 52$ & $0 \cdot 82 / 0 \cdot 70$ & $1 \cdot 19$ & $0 \cdot 62 / 0 \cdot 55$ & $0 \cdot 30 / 0 \cdot 26$ & 0.64 & $0 \cdot 61 / 0 \cdot 21$ & $277 / 261$ & \\
\hline 50 & $0.57 / 0.56$ & $0 \cdot 82 / 0 \cdot 70$ & $1 \cdot 19$ & $0 \cdot 65 / 0 \cdot 60$ & $0 \cdot 44 / 0 \cdot 44$ & $0 \cdot 80$ & $0 \cdot 83 / 0 \cdot 15$ & $263 / 283$ & \\
\hline 60 & $0.54 / 0.53$ & $0.82 / 0.71$ & $1 \cdot 18$ & $0 \cdot 69 / 0 \cdot 58$ & $0.59 / 0.47$ & 0.81 & $0.97 / 0.09$ & $225 / 311$ & \\
\hline
\end{tabular}

Note: The data in this table were presented as p-Pt/p-PtRu electrodes.

oxidation should differ from those intermediates of methanol oxidation. Ethanol should produce more reaction intermediates such as acetaldehyde and acetic acid which can be adsorbed strongly on the $\mathrm{Pt}$ surface than methanol. ${ }^{111,13,14}$ The oxidation pathway of ethanol on p-Pt electrode can be explained by the following mechanism: ${ }^{1}$

$$
\begin{aligned}
& \mathrm{Pt}+\mathrm{CH}_{3}-\mathrm{CH}_{2} \mathrm{OH} \rightarrow \mathrm{Pt}-\mathrm{CHOH}-\mathrm{CH}_{3}+\mathrm{H}^{+}+\mathrm{e}^{-} \\
& \mathrm{Pt}-\mathrm{CHOH}-\mathrm{CH}_{3} \rightarrow \mathrm{Pt}-\mathrm{CHO}-\mathrm{CH}_{3}+\mathrm{H}^{+}+\mathrm{e}^{-} \\
& \mathrm{Pt}-\mathrm{CHO}-\mathrm{CH}_{3} \rightarrow \mathrm{Pt}-\mathrm{CO}-\mathrm{CH}_{3}+\mathrm{H}^{+}+\mathrm{e}^{-} \\
& \mathrm{Pt}-\mathrm{CO}-\mathrm{CH}_{3}+\mathrm{Pt} \rightarrow \mathrm{Pt}-\mathrm{CO}+\mathrm{Pt}_{-} \mathrm{CH}_{3}
\end{aligned}
$$

and then

$$
\begin{aligned}
& \mathrm{Pt}-\mathrm{CO}+\mathrm{Pt}-\mathrm{OH} \rightarrow \mathrm{Pt}-\mathrm{COOH}+\mathrm{H}^{+}+\mathrm{e}^{-} \\
& \mathrm{Pt}-\mathrm{COOH}+\mathrm{Pt}-\mathrm{OH} \rightarrow \mathrm{CO}_{2}+\mathrm{H}_{2} \mathrm{O}+2 \mathrm{Pt} .
\end{aligned}
$$

Cyclic voltammograms in figure $1 \mathrm{c}$ of the electrooxidation of 1-propanol showed the onset potential around $0.74 \mathrm{~V}$ vs SHE which was more positive than other alcohols. This may be attributed to the de-protonation of 1-propanol during adsorption, suggested by Rodrigues et al. ${ }^{15}$ The 1-propanol was oxidized at potential higher than $0.5 \mathrm{~V}$ and was detected the oxidation product by DEMS and FTIR techniques. ${ }^{15,16}$

The relativities of electro-oxidation of alcohols estimated from the current density of $\mathrm{O}_{1}^{\mathrm{f}}$ peak are in the order: methanol $>$ ethanol $>1$-propanol at the same temperature. The increasing in the anodic current with the number of carbon atom in aliphatic alcohol indicates that it is more difficult to cleave
$\mathrm{C}-\mathrm{C}$ bond to be adsorbed $\mathrm{CO}\left(\mathrm{CO}_{\text {ads }}\right)$ and then also produce many reaction intermediate species. ${ }^{13}$ These adsorbed intermediates inhibit the electro-oxidation reaction and lead to increase the onset potential and decrease in current density as summarized in table 1 . However, the electro-oxidation efficiency for all alcohols increased when the temperature was raised. This indicates that the increasing temperature can enhance the rate of electro-oxidation of alcohols.

Figures $1 \mathrm{~d}-\mathrm{f}$ show the $\mathrm{CV}$ of the electro-oxidation of methanol, ethanol and 1-propanol with Ru modified platinized platinum (p-PtRu) electrode with $\mathrm{Ru}$ coverage $\left(\theta_{\mathrm{Ru}}\right)$ of 0.6 at various temperatures. For the electro-oxidation of methanol, the higher in current density of $\mathrm{O}_{1}^{\mathrm{f}}$ peak and lower in current density of $\mathrm{O}^{\mathrm{b}}$ peak were observed when compared with $\mathrm{p}-\mathrm{Pt}$ electrode. The $E_{\text {onset }}$ around $0.47 \mathrm{~V}$ vs SHE was also obtained at $25^{\circ} \mathrm{C}$ (see table 1). These results suggested that the major roles of $\mathrm{Ru}$ promoter were to increase the $\mathrm{OH}_{\text {ads }}$ species or active $\mathrm{H}_{2} \mathrm{O}$ on the $\mathrm{Ru}$ surface which $\mathrm{CO}_{\text {ads }}$ was loosely bound with the $\mathrm{Pt}$ surface. This mechanism is known as the bifunctional mechanism. ${ }^{11,17}$

$$
\begin{gathered}
\mathrm{Pt}+\mathrm{CH}_{3} \mathrm{OH}_{\text {solution }} \rightarrow \mathrm{Pt}^{-\mathrm{CH}_{3} \mathrm{OH}_{\text {ads }}} \\
\mathrm{Pt}-\mathrm{CH}_{3} \mathrm{OH}_{\mathrm{ads}} \rightarrow \mathrm{Pt}-\mathrm{COH}_{\mathrm{ads}}+3 \mathrm{H}^{+}+3 \mathrm{e}^{-} \rightarrow \\
\mathrm{Pt}-\mathrm{CO}_{\text {ads }}+\mathrm{H}^{+}+\mathrm{e}^{-} \\
\mathrm{Ru}+\mathrm{H}_{2} \mathrm{O} \rightarrow{\mathrm{Ru}-\mathrm{OH}_{\mathrm{ads}}+\mathrm{H}^{+}+\mathrm{e}^{-}}^{\mathrm{Pt}-\mathrm{COH}_{\mathrm{ads}}+\mathrm{Ru}-\mathrm{OH}_{\mathrm{ads}} \rightarrow} \\
\mathrm{Pt}+\mathrm{Ru}+\mathrm{CO}_{2}+2 \mathrm{H}^{+}+2 \mathrm{e}^{-}
\end{gathered}
$$




$$
\begin{aligned}
& \mathrm{Pt}-\mathrm{CO}_{\mathrm{ads}}+\mathrm{Ru}-\mathrm{OH}_{\mathrm{ads}} \rightarrow \\
& \mathrm{Pt}+\mathrm{Ru}+\mathrm{CO}_{2}+\mathrm{H}^{+}+\mathrm{e}^{-} .
\end{aligned}
$$

With the increasing temperature, the increasing in peak current and unchanged in the position of $\mathrm{O}_{1}^{\mathrm{f}}$ peak was also observed. These results were similar with both ethanol and 1-propanol.

In order to compare the activity of the electrooxidation of alcohols on $\mathrm{p}-\mathrm{Pt}$ and $\mathrm{p}-\mathrm{PtRu}$ at different temperatures, the Tafel slope $(b)$ and apparent activation energy $\left(E_{a}\right)$ were estimated from $\mathrm{CV}$ data $^{3}$ in low potential range $(0.4-0.6 \mathrm{~V})$ and also summarized in table 1. For p-Pt electrode, the Tafel slope $(b)$ is in the order: methanol $<$ ethanol $<1$-propanol at $25^{\circ} \mathrm{C}$ and decreases with the increasing of the temperature. It is well known that the Tafel slope corresponds to the rate determining step as well as the number of electron transfer steps that precede it. The electro-oxidation of alcohols with the higher carbon atoms $\left(\mathrm{C}_{2}-\mathrm{C}_{3}\right.$ alcohols $)$ occur via complicate reactions compared with the $\mathrm{C}_{1}$ alcohols. These reactions produced many adsorbed intermediate species and blocked the active site of Pt surface. The intermediate species can be removed when increasing temperature, corresponded to the decreasing of Tafel slope.

Arrhenius plots of logarithm of exchange current density $\left(\log J_{0}\right)$ versus the reciprocal of temperature $\left(T^{-1}\right)$ provided the apparent activation energy from the slope of linear fitted as shown in figure 2. The apparent activation energy of methanol, ethanol and 1-propanol at p-Pt electrode were 70.4, 52.2 and $32.8 \mathrm{~kJ} \mathrm{~mol}^{-1}$, respectively. These values were in agreement with the results reported by Lee et al. ${ }^{11}$ The higher activation energy of methanol than ethanol and 1-propanol imply that the electro-oxidation process of methanol consists of the different pathways. For p-PtRu electrode, the apparent activation energy was lower than those found in $\mathrm{p}$-Pt electrode. This result indicated that Ru sites improved the electro-oxidation of all alcohols, especially for methanol and ethanol.

\subsection{Electrochemical impedance spectroscopy (EIS)}

The EIS technique was performed in order to study the reaction activity of the alcohol electrooxidation. ${ }^{4,18,19}$ The methanol oxidation showed different Nyquist plot patterns with various potentials at $25^{\circ} \mathrm{C}$ as shown in figure 3 . The different Nyquist patterns imply that the mechanism of the electrooxidation reaction differ at various potentials. The Nyquist plot shows the 'capacitive loop' and 'inductive loop' in the high and low frequency range, respectively. The diameter of both loops decreased with increasing potential from 0.4 to $0.6 \mathrm{~V}$ vs SHE in quadrant I. It is known that the size of capacitive loop imply the rate of reaction. Moreover, the rate of poisoning intermediate species can be considered from the appearance of inductive loop. ${ }^{4}$

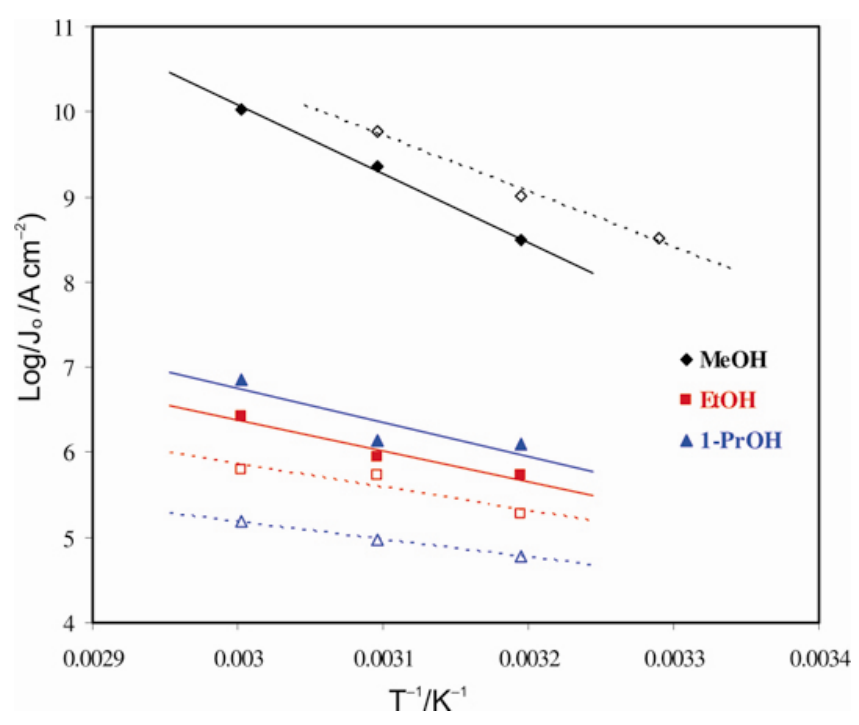

Figure 2. Arrhenius plot for methanol, ethanol and 1propanol at p-Pt (solid line) and p-PtRu (dash line) electrodes.

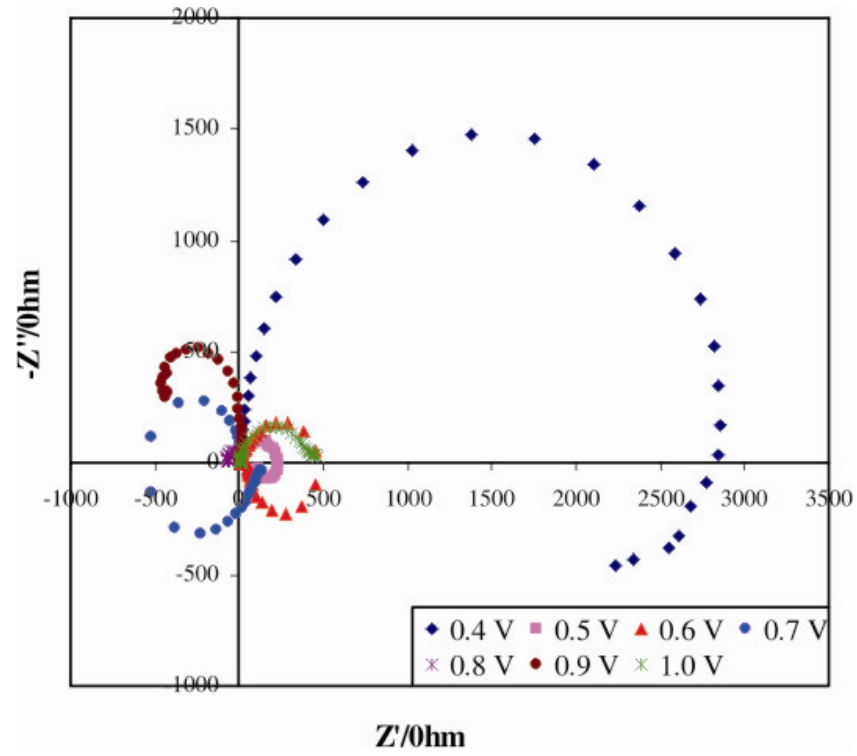

Figure 3. Nyquist plots for $0.25 \mathrm{M}$ methanol in $0.5 \mathrm{M}$ $\mathrm{H}_{2} \mathrm{SO}_{4}$ with $\mathrm{p}$-Pt electrode at different bias potential $(0 \cdot 4-$ $1 \cdot 0 \mathrm{~V}$ vs SHE). 

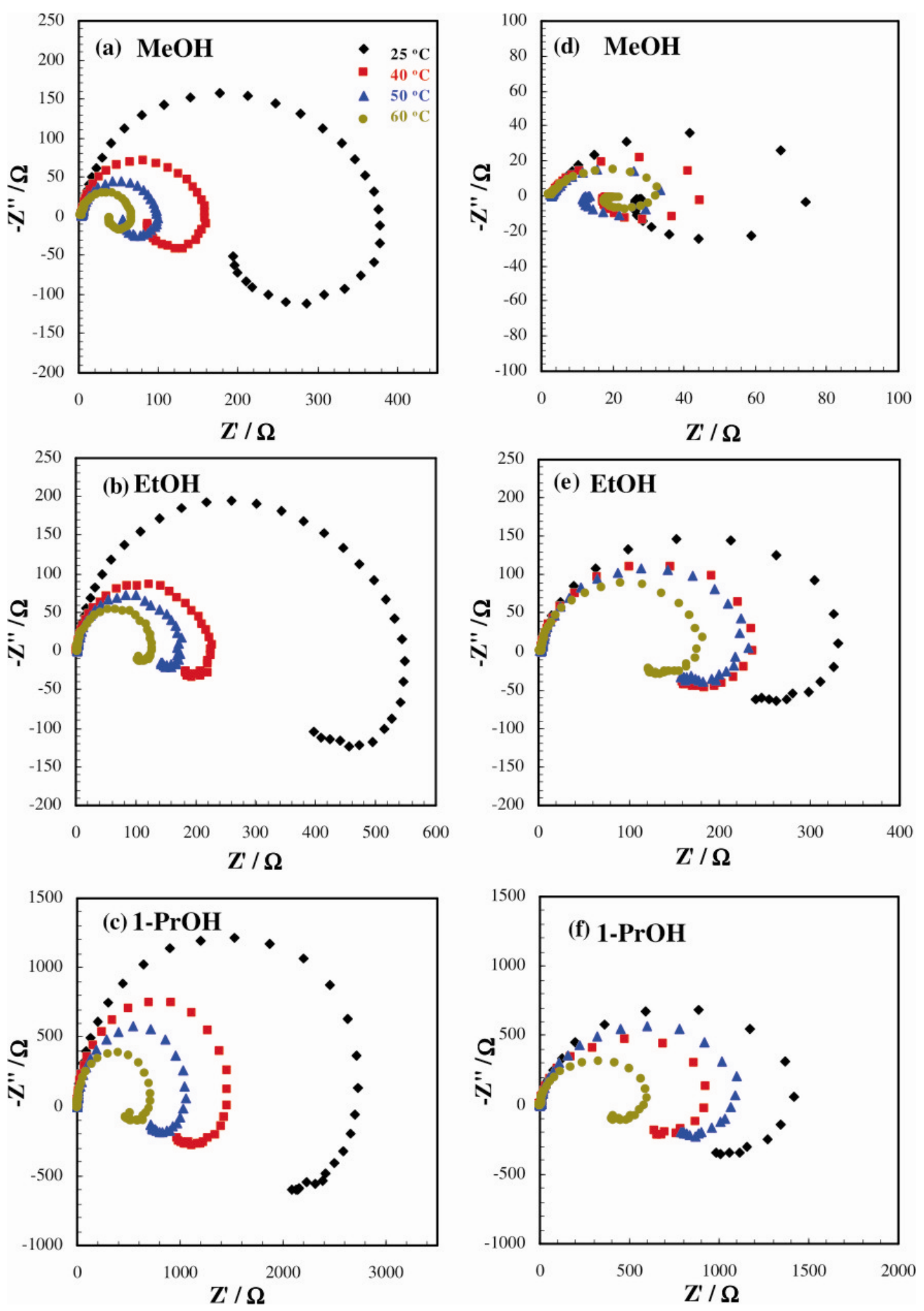

Figure 4. Nyquist plots at different temperatures with $\mathrm{p}$-Pt electrode and $(\mathrm{a}-\mathrm{c})$ and $\mathrm{p}-\mathrm{PtRu}$ electrode (d-f) in 0.25 M methanol, 0.25 $\mathrm{M}$ ethanol, and 0.25 $\mathrm{M}$ 1-propanol.

At the potential of $0.5 \mathrm{~V}$ vs SHE was considered as the occurrence of intermediate species. This provided the direct electrochemical evidence for the fact that $\mathrm{CO}_{\text {ads }}$ was being oxidized on the Pt sur- face, ${ }^{20}$ so we selected this bias potential for EIS study in this work. At the potential of $0.5 \mathrm{~V}$, the $\mathrm{Ny}$ quist plots for methanol, ethanol and 1-propanol in $0.5 \mathrm{M} \mathrm{H}_{2} \mathrm{SO}_{4}$ on a $\mathrm{p}$-Pt electrode at various tempera- 
tures are shown in figures $4 \mathrm{a}-\mathrm{c}$. The diameter of capacitive loop decreased with increasing the temperature.

The equivalent circuit model in figure 5 is used for fitting the EIS spectra, ${ }^{19}$ and the two important parameters were used including: charge transfer resistance $\left(R_{c t}\right)$ and inductance $(L)$. The relationship between impedance values $(Z)$ and fitting parameters can be expressed as shown in equation (15)(16):

$$
\begin{aligned}
& Z=R_{S}+\left(\frac{1}{Z_{F}}+Y(j \omega)^{n}\right)^{-1} \\
& \frac{1}{Z_{F}}=\frac{1}{R_{c t}}+\frac{1}{R_{L}+j \omega L},
\end{aligned}
$$

where $R_{S}$ is the solution resistance, $Z_{F}$ is the faradaic impedance, $\omega$ is the angular frequency, $Y_{0}$ and $n$ are two components of constant phase element $\left(Q_{C P E}\right)$, $R_{c t}$ is the charge transfer resistance, $R_{L}$ is the inductive resistance, $L$ is the inductance.

The reaction steps of the electro-oxidation of alcohol pathways can be simplified in the following scheme:

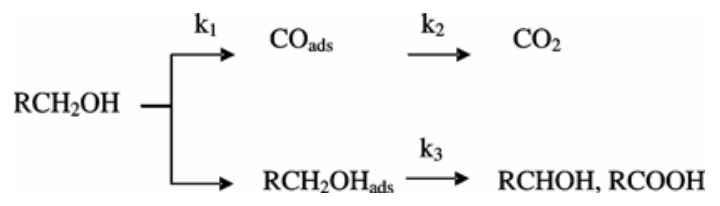

where $R$ is hydrogen or any alkyl group.

The first pathway occurs via dehydrogenation to COads which is the major intermediate species of the methanol electro-oxidation. Then, $\mathrm{CO}_{\mathrm{ads}}$ is oxidized with $\mathrm{OH}_{\text {ads }}$ or $\mathrm{H}_{2} \mathrm{O}_{\text {ads }}$ to $\mathrm{CO}_{2}$. The another pathway is the direct oxidation of alcohol to form acid or aldehyde which is observed by in situ FT-IR techniques. ${ }^{21,22}$ Above reaction pathway can explain from the relation of the reciprocal of charge-transfer resistance $\left(R_{c t}^{-1}\right)$ and inverse of inductance $\left(L^{-1}\right)$. The

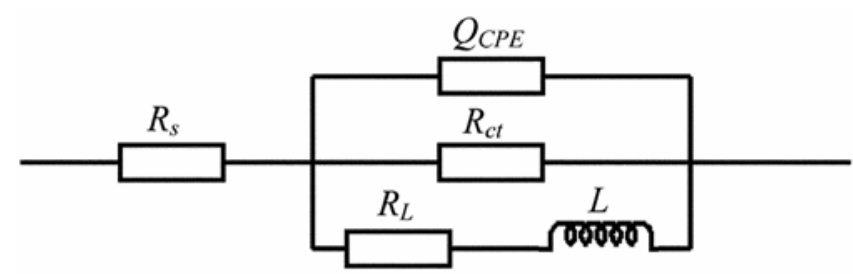

Figure 5. Equivalent circuit used for simulating the EIS spectra for the alcohol electro-oxidation on p-Pt and p$\mathrm{PtRu}$ electrodes at different temperatures. physical meaning of $R_{c t}^{-1}$ or the reciprocal of charge transfer resistance is the overall reaction rate when the concentration of intermediate on electrode surface is kept constant. The $L^{-1}$ can assume as the rate of oxidation for desorption of intermediate species on electrode surface, which mainly is $\mathrm{CO}_{\text {ads }}$.

Figure 6 shows the temperature dependent for $R_{c t}^{-1}$ and $L^{-1}$ values of $\mathrm{C}_{1}-\mathrm{C}_{3}$ alcohols on the $\mathrm{p}$-Pt and $\mathrm{p}-\mathrm{PtRu}$ electrodes. These results show that $R_{c t}^{-1}$ and $L^{-1}$ values increase with the rising temperature. The $R_{c t}^{-1}$ and $L^{-1}$ of methanol, ethanol and 1-propanol decreased with the increasing the number of carbon atom in alcohol chains. It is corresponded with the decreasing in anodic current observed from $\mathrm{CV}$ results. It is possible that the breaking $\mathrm{C}-\mathrm{C}$ bond process to $\mathrm{CO}_{\mathrm{ads}}$ is difficult in the first pathway. Moreover, the smaller in $L^{-1}$ values of both ethanol and 1-propanol than methanol also indicated the slower in the desorption rate of adsorbed species on the Pt surface. ${ }^{23}$ It is possible that the numbers of $\mathrm{CO}_{\text {ads }}$ decreased or the other intermediate species were strongly adsorbed and inhibited electrooxidation process. Moreover, it is possible that the adsorbed species could be further oxidized another oxidation pathway. According to the lower in apparent activation energy values of both ethanol and 1propanol, it is indicated that the electro-oxidation of these alcohols occur via the second pathway. Because of the activation energy of the $\mathrm{CO}_{\text {ads }}$ oxidation should be higher than the $\mathrm{C}-\mathrm{C}$ breaking bond.

The enhancement effect of Ru modified Pt surface on the electro-oxidation of methanol are also found in figure 6 . The $L^{-1}$ value increased with the excessively increasing temperature. This result suggested that the adding of $\mathrm{Ru}$ can improve the electrooxidation of methanol and the strong adsorbed $\mathrm{CO}_{\text {ads }}$ can be easily oxidized to $\mathrm{CO}_{2}$. This effect is also found in the ethanol oxidation, while 1-propanol oxidation is not significantly different.

\section{Conclusions}

The effect of temperature on the electro-oxidation of all alcohols on p-Pt and p-PtRu electrodes was explored by cyclic voltammetry and electrochemical impedance spectroscopy. The increase in anodic current and decrease in $R_{c t}$ value indicated that the reaction rate would be enhanced at higher temperature. The major roles of $\mathrm{Ru}$ sites were to increase the water adsorption and $\mathrm{OH}_{\mathrm{ads}}$ formation on $\mathrm{Ru}$ site. From the Arrhenius analysis, the activation energy 

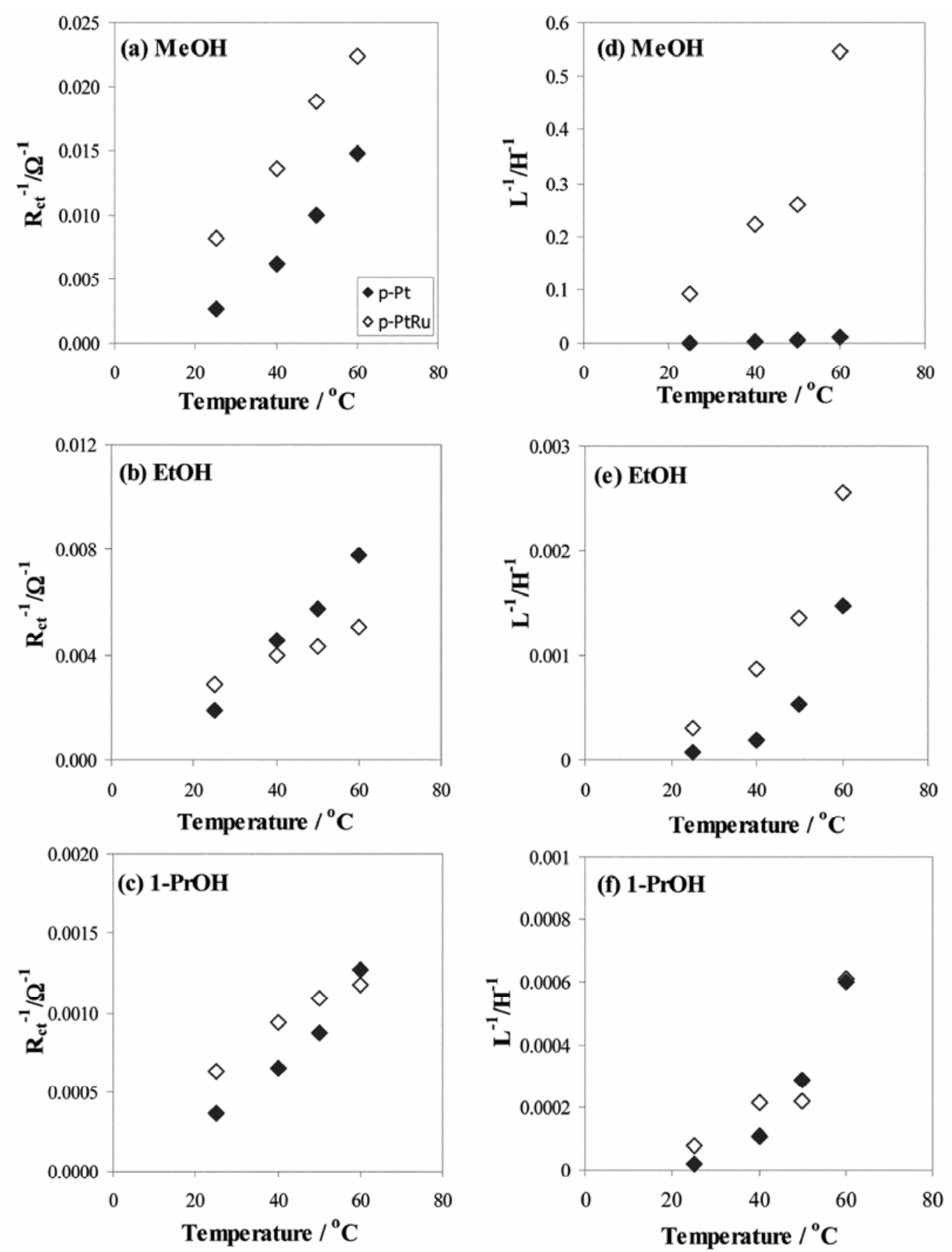

Figure 6. Plot of $R_{c t}^{-1}(\mathbf{a}-\mathbf{c})$ and $L^{-1}(\mathbf{d}-\mathbf{f})$ versus temperature for the electro-oxidation of $0.25 \mathrm{M}$ methanol, $0.25 \mathrm{M}$ ethanol, and $0.25 \mathrm{M}$ 1-propanol on $(\diamond) \mathrm{p}$-Pt and $(\diamond) \mathrm{p}$-PtRu electrodes.

of methanol, ethanol and 1-propanol electrooxidation on p-Pt electrode were $70.4,52.2$ and $32.8 \mathrm{~kJ} \mathrm{~mol}^{-1}$, respectively. It is possible to explain that both ethanol and 1-propanol also occur via the $\mathrm{C}-\mathrm{C}$ bond breaking pathway and lead to the lower of $E_{\text {a }}$ value. The EIS results shown that the electrooxidation of methanol prefer occurs via the electro- oxidation of $\mathrm{CO}_{\text {ads }}$ species, while ethanol and 1propanol occur via the oxidation of alcohol $\left(\mathrm{RCH}_{2} \mathrm{OH}_{\mathrm{ads}}\right)$ to acid or aldehyde. The $R_{c t}^{-1}$ and $L^{-1}$ values were higher when modified surface electrode by $\mathrm{Ru}$, especially for methanol and ethanol oxidation. However, the Ru modified surface cannot improve the electro-oxidation of 1-propanol. 


\section{Acknowledgements}

The authors are grateful to the Institutional Strengthening Program from Faculty of Science, Mahidol University, Bangkok, Thailand and the Center for Innovation in Chemistry, Post-Graduate Education and Research Program in Chemistry (PERCH-CIC), Mahidol University, Bangkok, Thailand for the financial support.

\section{References}

1. Gupta S S and Datta J 2006 J. Electroanal. Chem. 59465

2. Zhou W J et al 2004 J. Power Sources 12616

3. Wu G, Li L and Xu B-Q 2004 Electrochim. Acta 501

4. Otomo J, Li X, Kobayashi T, Wen C-J, Nagamoto $\mathrm{H}$ and Takahashi H 2004 J. Electroanal. Chem. 573 99

5. Lamy C, Lima A, LeRhun V, Delime F, Coutanceau C and Léger J-M 2002 J. Power Sources 105283

6. Song S, Zhou W, Liang Z, Cai R, Sun G, Xin Q, Stergiopoulos V and Tsiakaras P 2005 Appl. Catal. B: Environmental $\mathbf{5 5} 65$

7. Liu H, Song C, Zhang L, Zhang J, Wang H and Wilkinson D P 2006 J. Power Sources 15595

8. Dubau L, Hahn F, Coutanceau C, Léger J-M and Lamy C 2003 J. Electroanal. Chem. 554-555 407

9. Léger J-M, Rousseau S, Coutanceau C, Hahn F and Lamy C 2005 Electrochim. Acta 505118
10. Waszczuk P, Wieckowski A, Zelenay P, Gottesfeld S, Coutanceau C, Léger J-M and Lamy C $2001 \mathrm{~J}$. Electroanal. Chem. $\mathbf{5 1 1} 55$

11. Lee C-G, Umedab M and Uchida I 2006 J. Power Sources 16078

12. Burstein G T, Barnett C J, Kucenak A R and Williams K R 1997 Catal. Today 38425

13. Schmidt V M, Ianniello R, Pastor E and González S 1996 J. Phys. Chem. 10017901

14. Colmati F, Antolini E and Gonzalez E R $2006 \mathrm{~J}$. Power Sources 15798

15. Rodrigues IdA, Souza J P I D, Pastor E and Nart F C 1997 Langmuir 136829

16. Pastor E, Wasmus S, Iwasita T, Arévalo S MCGl and Arvia A J 1993 J. Electroanal. Chem. 35097

17. Gojković SLj, Vidaković T R and Đurović D R 2003 Electrochim. Acta 483607

18. Chakraborty D, Chorkendorff I and Johannessen T 2006 J. Power Sources 1621010

19. Hsing I-M, Wang X and Leng Y-J 2002 J. Electrochem. Soc. 149 A615

20. Ciureanu M, Wang H and Qi Z 1999 J. Phys. Chem. B103 9645

21. Kabbabi A, Faure R, Durand R, Beden B, Hahn F, Léger J-M and Lamy C 1998 J. Electroanal. Chem. 44441

22. Vigier F, Gloaguen F, Léger J-M and Lamy C 2001 Electrochim. Acta $\mathbf{4 6} 4331$

23. Ratana T 2005 The mechanistic study of the electrooxidation reaction of small organic molecules on modified Pt electrodes by electrochemical impedance spectroscopy and other techniques (Ph.D. Dissertation). Mahidol University, Bangkok, Thailand 